\title{
Medical and Health Science Students' Perception Towards a Problem-Based Learning Method: A Case of Debre Tabor University
}

\section{Simegnew Kibret \\ Diriba Teshome (iD) \\ Efrem Fenta (D) \\ Metages Hunie (ID) \\ Moges Gelaw Taye (D) \\ Yewlsew Fentie (D) \\ Tadese Tamire (D)}

Department of Anesthesia, College of Medicine and Health Sciences, Debre

Tabor University, Debre Tabor, Ethiopia
Correspondence: Moges Gelaw Taye Department of Anesthesia, College of Medicine and Health Sciences, Debre Tabor University, Debre Tabor,

PO. Box: 272, Ethiopia

Email mgsglwty@gmail.com
Background: Problem-based learning is a student-centered innovative instructional approach in which students define their learning objectives by using triggers from the predefined problem case scenario. Problem-based learning is not about problem-solving; rather it uses appropriate problems to increase the problem-solving skills of students. This study aims to assess the medical and health science students' perception towards problembased learning method.

Methods: An institution-based descriptive cross-sectional study was employed. All available graduating class Medical and Health Science students were included in this study.

Results: More than half of the students (59.4\%) strongly agree that problem-based learning was helpful to understand basic sciences knowledge and $31.5 \%$ of the students disagree that tutors are prepared and qualified to run the session. Some of the students (27.3\%) disagree that tutors evaluate students fairly. About fifty-two percent of the students have used both books and Internets for self-directed learning.

Conclusion: More than half of students agree that problem-based learning helped them understand basic science knowledge. Some of the students disagree that tutors are prepared and qualified to run the session, and disagree that tutors evaluate students fairly.

Keywords: perception, medical and health science students, problem based learning

\section{Introduction}

Traditionally, health sciences students were taught using a pre-defined manual. This often ignores the importance of applying the concepts of basic sciences in a realworld situation. ${ }^{1}$ These shortcomings of traditional learning are overcome in Problem Based Learning (PBL). Problem-based learning turns the teachinglearning process from a passive to an active process. ${ }^{2,3}$ Problem-based learning (PBL) is a student-centered innovating instructional approach in which students define their learning objectives by using triggers from the predefined problem case scenario. Subsequently, the students do independently; they develop self-directed study before returning to the group to discuss. ${ }^{4}$

Problem-based learning in health sciences/medical education was first developed and implemented in the 1960s at McMaster University in Canada by Howard Barrows. ${ }^{4-6}$ Problem-based learning-based hybrid innovative model. ${ }^{7}$ It can be used as an instructional method in such a curriculum and even without any lectures or tutorial sessions, ${ }^{8}$ which can contribute to the development and promotion of selfdirected and lifelong learning, communication and teamwork skills, presentation 
skills, and develops students' motivation and enthusiasm towards their profession ${ }^{3,9,10}$ and maintains professional ethics and behavior. ${ }^{7,11}$

In PBL students are put in an active learning situation by giving them clinical problems and training them to identify what they need to learn to solve those problems. ${ }^{12}$ Typically a PBL tutorial involves a group of 5 to 8 students discussing and analyzing a common patient problem in two meetings over a week, each meeting lasting 2-3 hours. ${ }^{13}$

A New Innovative Medical Education Initiative with PBL-based curriculum had been launched in Ethiopia in February 2012 and the training of medical education using a new approach and curriculum was initiated. ${ }^{14} \mathrm{PBL}$ introduced in a curriculum concept has a relatively short history in Ethiopia and the College of Medicine Health Sciences at Debre Tabor University also adopted PBL as one of the key educational strategies when it designed innovative curricula for medicine and midwifery in 2013 as well as Anesthesia, Nursing, and Medical laboratory in 2016. ${ }^{15,16}$

There are many studies worldwide that suggest a positive impact of PBL on health sciences' students learning. However, there are no studies done on students' perception of the PBL session in Ethiopia. Although to know students' perception towards PBL has an important impact on the success or failure of PBL. Therefore, this study aims to assess the medical and health science students' perception towards problem-based learning method.

\section{Methods}

\section{Study Design, Setting and Period}

An institutional-based descriptive cross-sectional study was conducted at Debre Tabor University College of health sciences in Ethiopia. The college of health sciences adopted a hybrid innovative curriculum that incorporates PBL as a learning method with the support of Jhpiego in 2013. ${ }^{14}$ The college of health sciences has six departments and all departments implementing PBL as a learning method in weekly sessions. The study population of this survey was all graduating class medical and health science students of the college of health sciences at Debre Tabor University. This survey was conducted from December 01, 2020, to December 31, 2020.

\section{Study Design}

\section{Inclusion Criteria}

All graduating class health sciences college students who registered during the second semester of the academic year (2020) were included in this study.

\section{Exclusion Criteria}

All graduating class students who did not take consent.

\section{Sampling Technique}

This study is a survey-based study of graduating class students of medical and health science students.

\section{Sampling Size}

The College of health sciences has six departments; among these five of them have generic graduating class students. Department of medicine has 42 students, anesthesia 13 students, midwifery 49 , medical laboratory 21 students, and nursing 30 generic graduating class students. Based on the total number of students who participated in this survey was 155 .

\section{Data Collection Technique}

Data was collected using self-administered questionnaires and the questionnaires papered by collecting variables from the previous studies. It contains socio-demographic characteristics, students' perception, tutors' facilitation of the PBL sessions, and their fairness on students using five likert scale evaluation and utilization of self-directed learning resources, duration, and preferred places. ${ }^{17,18}$

\section{Data Quality Control}

The questionnaire was prepared in English. Data collectors and supervisors were trained on each item which includes the study tools, objective, relevance of the study, right of respondents. During data collection, regular supervision and follow-up were made. Investigators were crosschecked the completeness and consistency of data throughout the data collection period.

\section{Ethical Clearance}

Before conducting the study, an ethical clearance was obtained from Debre Tabor University's ethical review committee. After getting permission from departments, data collectors were taken written informed consent from each student. Participants were informed as they have full right to withdraw from the study if they feel discomfort. During the data collection process norms, values, and morals of students' were respected.

\section{Data Analysis}

The data was coded and entered into SPSS version 23 for analysis. Descriptive statistics were used to summarize data, and tables to display results. 


\section{Results}

A total of 143 students were participated in this survey with a response rate of $92.2 \%$. The participants consisted of 92 males and 51 females. These students were categorized into 2 different age groups: age $>22$ and $=<22$ years, among these $86 \%$ of the participants were with the age group of $<22$ years old. The majority of the respondents were midwifery which is $30 \%$ and followed by medicine students which accounts for $25.9 \%$ and the least was Anesthesia $8.4 \%$. Semester cumulative GPA were dichotomized into three groups $<2.75,2.75-3.5$, and $>3.5$. Of these 46.9 were with the semester CGPA of 2.75-3.5 (Table 1).

\section{Students' Perception to Problem-Based Learning}

The students' perception to problem-based learning (PBL) session benefits, which included 10 items, the majority reported that strongly agree PBL was helpful to understand basic sciences knowledge 85 (59.4\%), helps to develop their problem-solving skills $(52.4 \%)$ and motivated them to learn $(51.7 \%)$ (Table 2).

\section{Tutors' Facilitation of the Problem-Based Learning}

Regarding tutors' facilitation, $31.5 \%$ of the students disagreed that tutors are prepared and qualified to run the session, $27.3 \%$ of the students disagreed that tutors fairly evaluate students (Table 3).

\section{Learning Resources, Duration and Preferred Place for Self-Directed Learning} Learning resource for self-directed learning, among the students, both books and Internets were 52.4 and which

Table I Demographic Profile of Study Participants

\begin{tabular}{|l|l|l|l|}
\hline \multicolumn{2}{|l|}{ Variables } & Frequency & Percentage \\
\hline Age (years) & $<22$ & 123 & 86 \\
& $\leq 22$ & 20 & 14 \\
\hline Semester & $<2.75$ & 26 & 18. \\
CGPA & $2.75-3 / 5$ & 67 & 46.9 \\
& $>3.5$ & 50 & 35 \\
\hline \multirow{2}{*}{ Department } & Medicine & 37 & 25.9 \\
& Anesthesia & 12 & 8.4 \\
& INursing & 29 & 20.3 \\
& Midwifery & 44 & 30.8 \\
& Medical Laboratory & 21 & 14.7 \\
\hline
\end{tabular}

followed by books $21 \%$. A majority $53.1 \%$ reported that they spent 2 hours for self-directed learning, and $11.2 \%$ of the students spent only $<1$ hour. Preferred places for self-directed learning at both dormitory and library are the leading preferred places (41.3). The library was used alone by $23.1 \%$ of the students' (Table 4).

\section{Discussion}

Problem-based learning is an instructional strategy in which "problems are used as a trigger for learning; students collaborate in small groups; learning takes place under the guidance of a tutor; learning is studentinitiated, and the curriculum includes sufficient time for self-study. ${ }^{14}$

In this study we found that more than half of the students strongly agree that PBL was helpful to understand basic sciences knowledge; PBL helps to develop their problem-solving skills, and PBL motivated them to learn. Regarding student evaluation, some of the students $(31.5 \%)$ did not agree that tutors are prepared and qualified to run the session, $27.3 \%$ of the students did not agree that tutors fairly evaluate students.

Similarly, a study conducted by Wakode et al in first-year medical students found that student's response towards PBL was encouraging. Most students agreed to PBL session content, delivery of sessions, motivation, acquisition of learning skills and basic principles. Regarding students' evaluation of assessment fairness using PBL, 23\% were responded strongly unfair, ${ }^{19}$ this might be due to the workload of the tutor and some of the students might not be actively engaged in PBL sessions. The other possible justification for unfair student assessment could be the unfamiliarity of PBL was introduced in a relatively short history in Ethiopia as one of the key educational strategies.

In a study conducted by Aldayel et al more than half of the students reported that PBL session increased their knowledge of basic sciences, and agreed that PBL provided better integration of basic with clinical sciences. ${ }^{17}$ This might be due to PBL is a student centered teaching methodology which maintains students better clinical judgment for real case scenarios.

In this study, the students reported that some of the students (52.4\%) used the internet, and $21 \%$ used books as learning resources. A study done on students' perception towards the problem-based learning tutorial 
Table 2 Students' Perception to Problem-Based Learning (PBL) Session Benefits

\begin{tabular}{|c|c|c|c|c|c|c|}
\hline \multirow[t]{2}{*}{ S. No } & \multirow[t]{2}{*}{ Items } & $\begin{array}{l}\text { Strongly } \\
\text { Agree }\end{array}$ & Agree & Neutral & Disagree & $\begin{array}{l}\text { Strongly } \\
\text { Disagree }\end{array}$ \\
\hline & & $\begin{array}{l}\text { Frequency } \\
\text { (\%) }\end{array}$ & $\begin{array}{l}\text { Frequency } \\
\text { (\%) }\end{array}$ & $\begin{array}{l}\text { Frequency } \\
\text { (\%) }\end{array}$ & $\begin{array}{l}\text { Frequency } \\
\text { (\%) }\end{array}$ & $\begin{array}{l}\text { Frequency } \\
\text { (\%) }\end{array}$ \\
\hline 1 & PBL helps meto understand basic sciencesknowledge & $85(59.4)$ & $52(36.4)$ & $2(1.4)$ & $\mathrm{I}(0.7)$ & $3(2.1)$ \\
\hline 2 & PBL helps meto increase mybasic sciencesknowledge & $70(49.0)$ & $61(42.7)$ & $7(4.9)$ & $4(2.8)$ & $\mathrm{I}(0.7)$ \\
\hline 3 & $\begin{array}{l}\text { The knowledgegained is morethorough PBLthan } \\
\text { lectures. }\end{array}$ & $67(46.9)$ & $46(32.2)$ & $17(11.9)$ & II (7.7) & $2(1.4)$ \\
\hline 4 & I feel that I learnbetter in PBLthan lectures & $45(31.5)$ & $62(43.4)$ & $23(16.1)$ & II (7.7) & $2(1.4)$ \\
\hline 5 & PBL motivates meto learn & $74(51.7)$ & $50(35.0)$ & $14(9.8)$ & $2(1.4)$ & $3(2.1)$ \\
\hline 6 & $\begin{array}{l}\text { PBL providesbetter integrationbetween basicand } \\
\text { clinicalsciences. }\end{array}$ & $54(37.8)$ & $52(36.4)$ & $26(18.2)$ & $9(6.3)$ & $2(1.4)$ \\
\hline 7 & $\begin{array}{l}\text { PBL tutorialsmake me discussinformation in } \\
\text { aprofessional way. }\end{array}$ & $48(33.6)$ & $51(35.7)$ & $25(17.5)$ & $17(11.9)$ & $2(1.4)$ \\
\hline 8 & PBL encouragesself-directedlifelong learning & $68(47.6)$ & $56(39.2)$ & $13(9.1)$ & $5(3.5)$ & $\mathrm{I}(0.7)$ \\
\hline 9 & $\begin{array}{l}\text { PBL method helpsme improve mydecision- } \\
\text { makingskills }\end{array}$ & $63(44.1)$ & $60(42.0)$ & $14(9.8)$ & $3(2.1)$ & $3(2.1)$ \\
\hline 10 & $\begin{array}{l}\text { PBL method helps to develop myproblem-solving } \\
\text { skills. }\end{array}$ & $75(52.4)$ & $57(39.9)$ & $7(4.9)$ & $2(1.4)$ & $2(1.4)$ \\
\hline
\end{tabular}

Table 3 Tutors' Facilitation of the Problem-Based Learning (PBL) Sessions and Their Fairness on Students' Evaluation

\begin{tabular}{|l|l|l|l|l|l|l|}
\hline S. No & Items & $\begin{array}{l}\text { Strongly } \\
\text { Agree Frequency } \\
(\%)\end{array}$ & $\begin{array}{l}\text { Agree } \\
\text { Frequency } \\
(\%)\end{array}$ & $\begin{array}{l}\text { Neutral } \\
\text { Frequency } \\
\text { (\%) }\end{array}$ & $\begin{array}{l}\text { Disagree } \\
\text { Frequency } \\
\text { (\%) }\end{array}$ & $\begin{array}{l}\text { Strongly } \\
\text { Disagree Frequency } \\
\text { (\%) }\end{array}$ \\
\hline I & $\begin{array}{l}\text { Tutors arepreparedand qualifiedto } \\
\text { run thesession }\end{array}$ & $24(16.8)$ & $48(33.6)$ & $26(18.2)$ & $32(22.4)$ & $13(9.1)$ \\
\hline 2 & Tutorsevaluatestudents infair way & $26(18.2)$ & $50(35.0)$ & $28(19.6)$ & $19(13.3)$ & $20(14.0)$ \\
\hline 3 & $\begin{array}{l}\text { Tutorfeedbackswere helpfulto } \\
\text { improvestudents'performance }\end{array}$ & $46(32.2)$ & $73(51.0)$ & $15(10.5)$ & $2(1.4)$ & $7(4.9)$ \\
\hline
\end{tabular}

session in a system-based hybrid curriculum in Saudi Arabia by Al-Drees et al reported that the majority of students used the internet (93.1\%), and books (64.4\%) as learning resources. ${ }^{20}$

The main limitation of this study could be it is a singlecentered study and only conducted in graduating class students.

\section{Conclusion}

Student's perception towards PBL session content, delivery of sessions, motivation, acquisition of learning skills and basic principles was encouraging. However, students' perception towards the evaluation of assessment using PBL was unfair. We recommend that to create awareness towards PBL tutoring for tutors and students, and students' 
Table 4 Learning Resources, Duration and Preferred Place for Self-Directed Learning

\begin{tabular}{|l|l|l|l|}
\hline \multicolumn{2}{|l|}{ Items } & Frequency & Percentage \\
\hline Self-directed learning & Internet & 23 & 16.1 \\
resources & Books & 30 & 21.0 \\
& Medical journal & 4 & 2.8 \\
& Lecture notes & 11 & 7.7 \\
& Both book and internet & 75 & 52.4 \\
\hline Duration for self-directed & Less than an hour & 16 & 11.2 \\
learning & 2 hours & 76 & 53.1 \\
& $>$ hhours & 51 & 35.7 \\
\hline Preferred place for self- & Library & 33 & 23.1 \\
directed learning & Dormitory & 48 & 33.6 \\
& Library and Dormitory & 59 & 41.3 \\
\hline
\end{tabular}

recommendations should be into consideration to provide students with a favorable learning environment and to improve tutors assessment.

\section{Abbreviations}

PBL, problem based learning; CGPA, cumulative grade point average.

\section{Data Sharing Statement}

All datasets of this study are available from the corresponding author on reasonable request.

\section{Acknowledgment}

Debre Tabor University

\section{Disclosure}

The authors report no conflicts of interest in this work.

\section{References}

1. Matsuo O, Takahashi Y, Abe C, Tanaka K, Nakashima A, Morita H. Trial of integrated laboratory practice. Adv Physiol Educ. 2011;35 (2):237-240. doi:10.1152/advan.00047.2010

2. Neville AJ, Norman GR. PBL in the undergraduate MD program at McMaster University: three iterations in three decades. Acad Med. 2007;82(4):370-374. doi:10.1097/ACM.0b013e318033385d

3. Preeti B, Ashish A, Shriram G. Problem based learning (PBL)-an effective approach to improve learning outcomes in medical teaching. J Clin Diagn Res. 2013;7(12):2896.

4. Wood DF. Problem based learning. BMJ. 2003;326(7384):328-330. doi: $10.1136 /$ bmj. 326.7384 .328

5. Olson J. The McMaster philosophy: a student's perspective on implementation. Med Edu. 1987;21(4):293-296. doi:10.1111/j.13652923.1987.tb00366.x
6. Neville AJ, Learning P-B. Medical education forty years on. A review of its effects on knowledge and clinical performance. Med Principles Pract. 2009;18:1-9. doi:10.1159/0001 63038

7. Bin Abdulrahman KA. The current status of medical education in the Gulf Cooperation Council countries. Ann Saudi Med. 2008;28 (2):83-88. doi:10.5144/0256-4947.2008.83

8. Masek A, Yamin S. Problem based learning model: a collection from the literature. Asian Soc Sci. 2010;6(8):148. doi:10.5539/ass. v6n8p148

9. Dolmans D, Schmidt H. The advantages of problem-based curricula. Postgrad Med J. 1996;72(851):535-538. doi:10.1136/ pgmj.72.851.535

10. Patel VL, Groen GJ, Norman GR. Effects of conventional and problem-based medical curricula on problem solving. Academic Medicine. 1991;66(7):380-389. doi:10.1097/00001888-19910700000002

11. Seshaiah S, Jagadish V. Problem-Based Learning as a Tool in Anesthesia PG Teaching-A Cross Sectional Study; 2016.

12. Al-Naggar RA, Bobryshev YV. Acceptance of problem based learning among medical students. Journal Of Community Medicine And Health Education. 2012;2(5). doi:10.4172/21610711.1000146

13. Kelson A, Distlehorst L. Groups in problem-based learning (PBL): essential elements in theory and practice. Problem-Based Learning: A Research Perspective on Learning Interactions. 2000;167-184.

14. Abraham Y, Azaje A. The new innovative medical education system in Ethiopia: background and development. Ethiopian $J$ Health Develop. 2013;27(1):36-40.

15. Wondie A, Yigzaw T, Worku S. Effectiveness and key success factors for implementation of problem-based learning in Debre Tabor University: a mixed methods study. Ethiop J Health Sci. 2020;30:5.

16. Asefa M. Brief Communication: imaginative, Innovative, and Creative Curriculum (IICC). Ethiopian J Educ Sci. 2008;3 (2):107-119. doi:10.4314/ejesc.v3i2.42010

17. Aldayel AA, Alali AO, Altuwaim AA, et al. Problem-based learning: medical students' perception toward their educational environment at Al-Imam Mohammad Ibn Saud Islamic University. Advan Med Educ Pract. 2019;10:95. doi:10.2147/AMEP.S189062 
18. Chilkoti G, Wadhwa R, Kumar A. Status of problem based learning in postgraduate anesthesia teaching: a cross-sectional survey. Saudi $J$ Anaesth. 2015;9(1):64. doi:10.4103/1658-354X.146316

19. Wakode S, Wakode N, Khobragde R, Tambe M, Tajne V, Mishra N. Perception on problem based learning sessions amongst first year medical graduates of central India. Scholars J Appl Med Sci. 2016;4(7):2572-4.
20. Al-Drees AA, Khalil MS, Irshad M, Abdulghani HM. Students' perception towards the problem based learning tutorial session in a system-based hybrid curriculum. Saudi Med J. 2015;36(3):341. doi:10.15537/smj.2015.3.10216

\section{Publish your work in this journal}

Advances in Medical Education and Practice is an international, peerreviewed, open access journal that aims to present and publish research on Medical Education covering medical, dental, nursing and allied health care professional education. The journal covers undergraduate education, postgraduate training and continuing medical education including emerging trends and innovative models linking education, research, and health care services. The manuscript management system is completely online and includes a very quick and fair peer-review system. Visit http://www.dovepress.com/testimonials.php to read real quotes from published authors. 